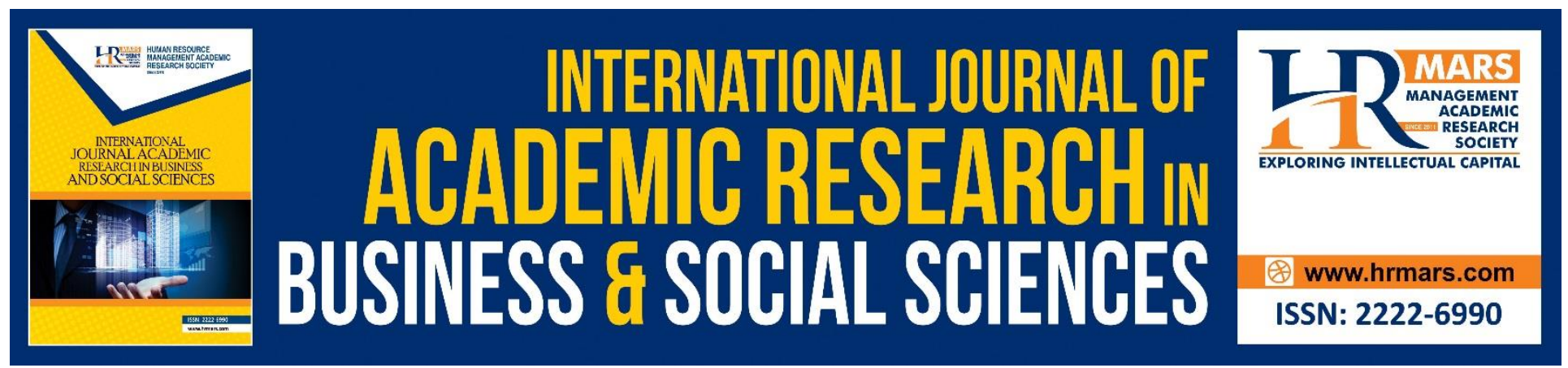

\title{
Banks Regulation and Performance in the Context of Commercial Banks in Kenya
}

Blandina Walowe Kori, Stephen M. A. Muathe, Samuel Mwangi Maina

To Link this Article: http://dx.doi.org/10.6007/IJARBSS/v10-i10/7918

DOI:10.6007/IJARBSS/v10-i10/7918

Received: 08 August 2020, Revised: 30 August 2020, Accepted: 19 September 2020

Published Online: 09 October 2020

In-Text Citation: (Kori, Muathe, \& Maina, 2020)

To Cite this Article: Kori, B. W., Muathe, S. M. A., \& Maina, S. M. (2020). Banks Regulation and Performance in the Context of Commercial Banks in Kenya. International Journal of Academic Research in Business and Social Sciences. 10(10), 65-79.

\section{Copyright: (c) 2020 The Author(s)}

Published by Human Resource Management Academic Research Society (www.hrmars.com)

This article is published under the Creative Commons Attribution (CC BY 4.0) license. Anyone may reproduce, distribute, translate and create derivative works of this article (for both commercial and non-commercial purposes), subject to full attribution to the original publication and authors. The full terms of this license may be seen at: $\underline{\text { http://creativecommons.org/licences/by/4.0/legalcode }}$

Vol. 10, No. 10, 2020, Pg. 65 - 79

http://hrmars.com/index.php/pages/detail/IJARBSS

Full Terms \& Conditions of access and use can be found at http://hrmars.com/index.php/pages/detail/publication-ethics 


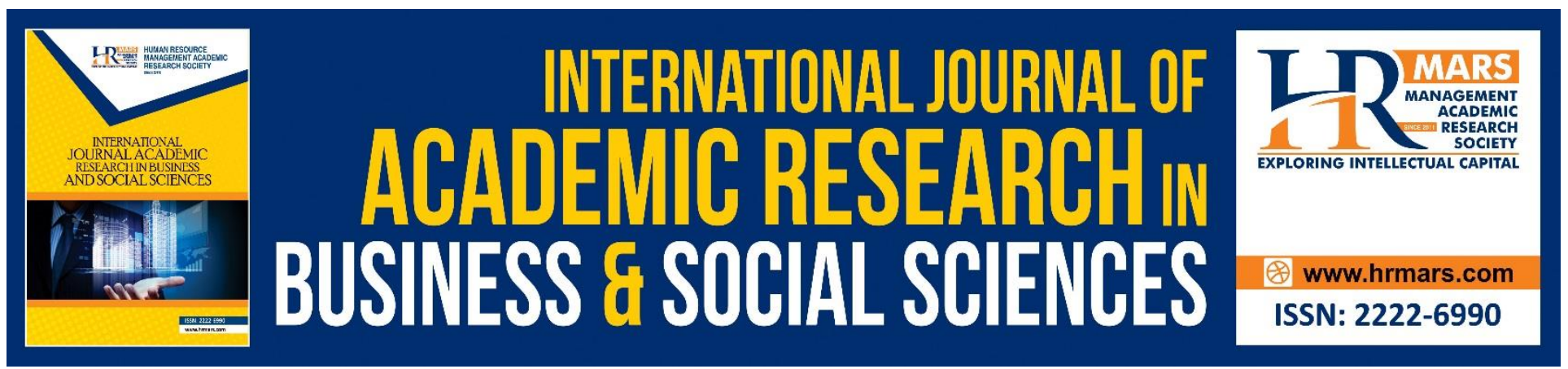

\title{
Banks Regulation and Performance in the Context of Commercial Banks in Kenya
}

\author{
Blandina Walowe Kori, Stephen M. A. Muathe, Samuel Mwangi \\ Maina
}

School of Business, Kenyatta University, Nairobi, Kenya

Email:mt.joseph@yahoo.com, muathesm@yahoo.com,sammaina2013@gmail.com

\begin{abstract}
The purpose of this study was to examine the effect of regulatory framework in commercial banks, in Kenyan context. The study evaluated commercial banks performance using both financial and nonfinancial performance measurers. The financial measurers for this study comprised return on equity (ROE), while non-financial measures were customer satisfaction, learning and growth, and internal processes. The study was anchored on resource-based view, dynamic capabilities and stakeholder theories. The targeted population for the study was 40 commercial banks and the sample size was 181 respondents selected proportionately through stratified sampling procedure. Data collection instruments comprised closed and open -ended questionnaires and online document review. This study used primary and secondary data, primary data was obtained from Kenya commercial banks head offices, while secondary data, for the year 2016 - 2018, was acquired from the annual publications by the central bank of Kenya. Data analysis was done using descriptive statistics and simple regression analysis. Findings of study indicate that regulatory framework has a statistically significance on the performance of commercial banks in Kenya but not to a large extent. Moreover, both financial and non-financial measures of performance are relevant in the banking sector and growth of Kenyan economy. The study recommends that regulators should not enforce restrictions on the expense of adverse effect on the investors.
\end{abstract}

Keywords: Bank Regulations, Performance, Commercial Banks in Kenya

\section{Introduction}

The development of banking system to took root during the medieval time from which more activities of commercial banks increased from lending of money to individuals, to financing complex government projects (Roussakis, 1997). The development in banking was accompanied with number of changes varying from innovations, financial regulations, savings and improvement of world economy (Buch, 2018). Commercial banks in Kenya for example provide credits for the development of the country's different projects to increase production and other economic development activities. Moreover, they distribute pooled saving to different sectors, hence ensuring proper utilization of resources for more productivity and economic growth (Johnson, Gunatilake, Niimi, Khan, Jiang, Hasan 
INTERNATIONAL JOURNAL OF ACADEMIC RESEARCH IN BUSINESS AND SOCIAL SCIENCES Vol. 10, No. 10, 2020, E-ISSN: 2222-6990 @ 2020 HRMARS

\& Huang, 2009). The wide range products and services rendered by the banks in Kenya are more less the same hence making it complicated to differentiate the extent contribution from an individual bank. To evaluate or determine the banks operation results and their financial conditions, evaluators can consider measures for an individual or the average industries' assets quality, management quality, efficiency or achievement of their objectives, earnings quality, liquidity, capital adequacy, and level of bank services (Kamande, 2017).

However, any good performance in a sector must be monitored to ensure consistence, hence the commercial banks are monitored through bank regulations (Barth, Caprio \& Levine, 2001). Bank regulations are government restrictions and guidelines to ensure that banks operate within the given directives. The regulators protect the interests of the banks' stakeholders by ensuring that there is transparence in the operations (Ping, 2014). Accordingly, transparence in the banking sectors gives good image to customers and all interested people (Iqbal \& Sami, 2017; Valls, Cruz \& Parra, 2020). In order to encourage more investment, commercial banks publish annual reports to show their position in the market (Henry, Robinson, \& van Greuning, 2012). Annual reports are a source of information stockholders and all interested parts can assess yearly banks operations, hence helping them to make informed decisions (Graybeal, Franklin \& Cooper, 2018). Thus, qualitative and quantitative reports are a source of commercial banks information, consequently bank should provide both qualitative and quantitative reports to avoid misleading stakeholders (Boussanni, Desrochers \& Préfontaine, 2008).

Some of the qualitative measurements indicators may include client survey scores measured through customer feedback or customer satisfaction records, average time taken to sort out queries from customers, customer won or customer loss, services levels and delivery, effective and efficiency among other indicators (Khadka \& Maharjan, 2017). On other hand quantity measurements may be evaluated through operating expenses as a percentage of assets (OER), assets under management (AUM) measured quarterly, percentage of AUM above benchmark used to evaluate how a particular bank rank compared to its competitors, return on equity (ROE) which evaluates returns on shareholder's equity, return on assets (ROA) which assesses the net income generated by the bank divided by the total assets or return on capital employed (ROCE) which determines a company's profitability and efficiency which should be higher than the capital cost (Ghebregiorgis \& Atewebrhan, 2016; Alshatti, 2015).

In essence, qualitative indicator of performance are assessed through non-financial data which are the best measurements for reflection of the strategic performance and implementation of strategic plan of a company. However, non-financial measures may be time consuming to evaluate and may also produce conflicting information from different sources of reactions. Moreover, non-financial data are measured in many ways, hence they lack a common denominator varying from time, quality or percentages which at the end may not produce concrete results due to lacking links which companies could have failed to state before choosing the type of indicator. They also lack statistical reliability which are bases for financial measures.

On other hand financial measures are mathematical modelling which can easily be used to rate a particular bank among others (Sharma, Shebalkov \& Yukhanaev, 2016). This implies that, financial indicators provide more precise information to facilitate investors' valuable decisions. This study adapted financial return on equity (ROE) as a measurer for performance in Kenya commercial banks, as noted it is an expression of a company's net income. ROE reflects the value of shareholders' returns 
INTERNATIONAL JOURNAL OF ACADEMIC RESEARCH IN BUSINESS AND SOCIAL SCIENCES Vol. 10, No. 10, 2020, E-ISSN: 2222-6990 @ 2020 HRMARS

and explains company's market value (Pennacchi \& Santos, 2018). Moreover, the measurer provides the rate of return on the investors' capital as opposed to return on assets (ROA) and return on capital employed (ROCE) (Kabajeh, Al Nuaimat \& Dahmash, 2012). Accordingly, the shareholders prefer the ROE in bank holdings since it is comparable against the cost of equity capital (COE). In essence, high ROE implies that the value created by the managers is cost effective and worthy investing in (Norman, 2017). According to Allen, Otchere and Senbet, (2011) commercial banks must encourage stockholders to invest more to maintain stability and sustainability of commercial banks, and sustain the liquidity flow for the growth of the country's economy. This is because there is close relationship between banking industry performance and the country 's economy (Liang, \& Reichert, 2006). To ensure proper control therefore, government appoints a regulatory board referred to as bank regulatory framework.

For this matter regulatory agencies maintain strict measures to keep the banks within the accepted operating standards (Levine, \& Barth, 2001). However, this is possible when regulators push it as noted by $\mathrm{Li}$ (2007) since most of the investors prefer a liberal business platform to achieve supernatural profits. In many cases governments are very cautious about the commercial banks' performance since any downward trend on the same, may require a bailout, on other hand unscrupulous business may cripple the nation's economy. The regulators are constantly on the look out to make sure that commercial banks are faithfully complying with the regulations (Chakrabarty, 2013).

Regulatory framework in banking sector is a government regulation intended to control the banking activities ((Levine \& Barth, 2001). The main aim is to ensure transparency between the banks, individual investors and other corporations. The banking regulations in a nation therefore, forms a financial law, which basically focus on the prudential or means and ways of reducing risk which investors are exposed to. They also work on reducing systematic risks which may be caused by adverse trading such as money laundering, which in the long run may result serious failure of the banks. Regulatory framework also works on protecting banking confidentiality, credit allocation to potential industries nations' economic cohorts.

In addition, the regulators ensure that they understand commercial banks activities such as savings, lending, hedging, and at times they may impose interest rate caps to ensure commercial banks stability (Sleem, 2010). As part of good governance practice, regulators often conduct internal and external evaluation (OECD, 2014). While internal performance evaluation is basically directed to securitizing the systems and processes, external regulators focus on evaluating the external goals such as taking care of the stakeholders' interest or the social funding for corporate responsibility, hence uplifting the standard of life in the citizen. Moreover, to maintain order in the industry regulatory framework, follow principles such as licensing and supervision of new banks. The licensing components is basically meant to ensure that all banks that are starting in a country must be legalized through an issue of a license.

This is meant to evaluate the new company's intent and ability to meet the regulatory guidelines set by the specific country on banks operations. Moreover, the regulators also supervise the already operating licensed banks for compliance and ensure that there is no any breach of the rules and regulations as stipulated in the licensing article. This may require inspection of the entity's records once in a while, to evaluate the annual reports and other banks' records simply to verify compliance. 
INTERNATIONAL JOURNAL OF ACADEMIC RESEARCH IN BUSINESS AND SOCIAL SCIENCES Vol. 10, No. 10, 2020, E-ISSN: 2222-6990 @ 2020 HRMARS

Another principle is the minimum capital ratio requirements imposed by the regulators to banks, this is to ensure that the banks are safe from risks of bankruptcy. Moreover, regulators ensure that banks maintain market discipline by enforcing the laws of transparency and other information to the investors.

The regulatory framework establishes a system of financial intermediation to enhance privatization, liberalization and foreign direct investment with the main aim of maintaining high performance in the industry, and nations/global economy as a whole (Djalilov \& Piesse, 2019). Some common sources of regulations include the parliaments or the legislatures, ministries, agencies and the voters from different plebiscites. Regulations exists in different form including rules and regulations, constitutions, legal laws or standards, depending on where they need be enforced. Accordingly, the regulation terms and concept are made clear to the entities directly concerned, since most of the time they are accompanied with penalties and or sanctions. As noted by Sleem (2010) during inspections and monitoring, the non-compliances are forced to pay heavy or light penalties depending on the weight of the misconduct. In many instances regulations are meant to improve behaviour of the banking industries to generate positive results to the economy of the country (OECD, 2014).

\section{Review of Literature \\ Theoretical Review}

This study was anchored on resource based-view (RBV), dynamic capabilities (DC), stakeholder theory. The RBV has its origin from a scholar Penrose (1958) accordingly, the scholar contends that a firm must consider that its resources are sufficient for the maintenance of the competitive advantage (Kor \& Mahoney, 2004). Accordingly, this is one way of examining a firm's position in the market based on its resources (Kim, Song \& Triche, 2015). However, RBV has been criticized that it does not show how firms integrate resources and capabilities in a competitive environment (Kraaijenbrink, Spender \& Groen, 2010). On other hand dynamic capabilities theory authored by Teece and Pisano (1994) assumes that firm processes to integrate, reconfigure, build and release resources that lead to changes in the market. Consequently, relationship among dynamic capabilities build competitive advantage (Medeiros, Christino, Goncalves \& Goncalves, 2020). The resourcesbased view and dynamic capabilities theories complement each other in that, while RBV emphasizes on sustainable competitive advantage, dynamic capabilities theory focuses on the organisational survival in rapid changing and tight competitive business environment (Wojcik, 2015). On hand stakeholder theory authored by Freeman 1984 base its argument on the relationship between stakeholder and competitive advantage. The theory assumes that stakeholder is key for the firm sustainability, that firms should not only concentrate in creating value for stockholders only, but they should consider the interconnectedness relationships between business and its stakeholders. In other words, both business profitability and stakeholders are key if a firm wants to obtain competitive advantage. This implies that stakeholders are capabilities synonymously the capabilities found in RBV and DC, such as human resources (Kor and Mahoney, 2004; Collins, 2020). Dynamic capabilities theory focusses on interior factors of the firm, its resources, competences and capabilities (Wojcik, 2015). On other hand RBV is said to be relevant and applicably within the organisational economics paradigm (Mahoney \& Pandian, 1992).

Stakeholder theory also assumes that where management cooperates with stakeholders, they became part of the organisation's key decision makers hence the achievement of the firm growth 
INTERNATIONAL JOURNAL OF ACADEMIC RESEARCH IN BUSINESS AND SOCIAL SCIENCES Vol. 10, No. 10, 2020, E-ISSN: 2222-6990 @ 2020 HRMARS

and competitiveness. The management of the firm here comprise of individual suppliers for entrepreneurial services and those they are suppling, in other words these stakeholders are a capability and key for the growth of firm (Kor, Mahoney, Siemsen \& Tan, 2016). Further RBV believes that the any type of resources possessed by the firm should be a source of strength which must enable them to formulate and implement the organisation strategies (Mahoney \& Pandian, 1992), and the objectives achieved through the said resources will depended on capability of the individual using them (Kor \& Mahoney, 2004), while the achievement of objective is made successful through the individual knowledge within the organisation therefore helps the managers to differentiate strategies which in RBV are rare resources.

One of such rare resources is knowledge of loyal stakeholder of the firm and source of temporary competitive advantage (Harrison, Bosse \& Phillips, 2007). This notion is found in the RBV, that differences in resources results to performance differences, while the dynamic capabilities theory believe that when different resources are well coordinate and integrated, they increase returns and value creation of the firm (Teece, Pisano \& Shuen, 1997). The customers willingness to pay for products are a different resource that make a firm come out differently from other firms which cannot break-even due to poor stakeholder relationship. This is what is referred to as a dynamic approach to stakeholder management to make them cooperate with the firm (Minoja, 2012). Manzaneque-Lizano, Alfaro-Cortés and Priego de la Cruz (2019) contend that the capacity of a firm to ensure sustainability depends on how they give stakeholder priority in their dealings. Transaction theory founded by Williamson (1985) posit that firms, specifically the commercial banks exists to overcome market failures, based on the principle of efficiency.

One way of overcoming market failure is by prioritizing stakeholders Vs. shareholder's interest, which accordingly, leads to profitability, liquidity and sustainability of the firm. An example of this is in financial market which is key in regulating the conflict between firm and stakeholders' interest (Hajer \& Anis, 2018). In this case internal and external mechanisms influence, monitor and control the behaviour of the managers and ensure that there is overall heathy business management (Hajer \& Anis, 2018). Basically, banking institutions are highly regulated by the government relatively more than any other institution, to address concerns over the safety and stability of the sector generally, and the payments system (Heimler, 2006).

The origin of regulation of business sectors came as a result of sector reform in OECD countries which brought about the regulatory policy (Malyshev, 2008). As noted by Hodge (2007) regulation is an intention to control behaviour and focuses on obtaining identified outcome according to set standards. The concept of regulation come in two forms namely positive theories of regulation and normative theories of regulation. The positive theories of regulation are from market power and basically focus on efficiency and the people who have interest of such a market, (the government and customers) (Hodge, 2007). On other hand normative theories are liberal, they suggest that regulators should encourage competition and information asymmetry, to strike a balance between profit maximization and ethical practices in business (Qaqaya, 2008). This study argues that both schools of thought should be accommodated in business operation, which implies that regulations should be flexible and democratic.

The framework on other hand is power structure, focused to attempt alter behaviour due to the foreseen benefit (Hodge, 2007). As noted, the regulatory framework focusses basically on institutions or sectors. Implementation of regulation is easy when the institutions are committed to 
INTERNATIONAL JOURNAL OF ACADEMIC RESEARCH IN BUSINESS AND SOCIAL SCIENCES Vol. 10, No. 10, 2020, E-ISSN: 2222-6990 @ 2020 HRMARS

obeying the law, thus they may take step to implement before the regulators (government) enforces it (Soimakallio \& Saikku, 2012). In normal circumstance institutions are caught in a situation where they experience a variety of non-regulatory factors such as economic and social pressure, which may force them to behave abnormally (Soimakallio \& Saikku, 2012). In such situation's regulation should adapt stakeholder theory and both positive and normative schools of thought come together and find the way forward.

\section{Empirical Review}

The financial sector regulatory framework in Kenya was established in 2009 by a forum comprising of Central Bank of Kenya (CBK), Capital Market Authority (CMA), Retirement Benefits Authority (RBA), Insurance Regulatory Authority (IRA) and Sacco Societies Regulatory Authority (SASRA) (CBK, 2013). The main aim was to ensure financial stability and give confidence to investor as well maintain the financial intermediation process and the economic standing of the nation (CBK, 2013). The forum offers informed discussions on major issues concerning financial sector in Kenya and provide stakeholder with reports concerning the development and performance of Kenyan economy, highlight major risks to the economy, and provide policies to mitigate the potential risks to economy before they disrupt the country's economy (M'Amanja, 2015). The Central Bank of Kenya together with other regulatory forum supervises the mortgage finance company, the microfinance banks, the representative offices of foreign banks, the foreign exchange bureaus, the money remittance providers and the credit reference bureaus (Financial Sector Regulators Forum, 2018; Cytonn, 2018). In essence they safeguard financial systems stability to ensure the monetary and macroeconomic stability in the country's economy (Mwega, 2016).

Accordingly, the banks in Kenya operate under the guidelines of the Kenyan Constitution Act no. 488 for banking, and the Central Bank of Kenya Act 491 (Momanyi, 2018). The licensing and regulating Act for commercial banks and the mortgage finance institutions is applied to both intuitions in accordance with the banking Act of Kenya. The major objective for supervision is to ensure that the banking sector is stable and resilient enough to counter challenge of the volatile economy in the country (CBK, 2017). Accordingly, the statutory objects of the CBK Act (Cap 491) promote financial standing through maintaining sound management in the banking sector. Thus, the Central Bank ensures that every licensed financial institution works under strictly minimum financial standing, hence ascertaining the banking institutions effectiveness while identifying, measuring, monitoring and controlling any potential foreseen dangers.

Moreover, the central bank enhances investment of the country through different mechanism, the most current and specific be the support of the Kenya Vision 2030. Accordingly, the government expects financial sector services to provide intermediation between savings and investments for the Vision 2030 goals, which aim to uplift the life standards of its people by making Kenya an industrialized nation. To achieve this therefore, the government identified financial sector as one of the six sectors capable for driving this project. The current government's economic deliverables are geared toward achieving the Vision through "The Big Four" agenda (Gu, Chua \& Trebs, 2020).

Additionally, banks regulatory framework is expected to ensure revisiting the suggested implementation of legal and intuitional reforms in the financial sector (Griffith-Jones, 2016). A lot of work has been done concerning financial sector in Kenya and economic performance; Mwega. (2016); Kamau, \& Were, (2013); Griffith-Jones, (2016); Musau, Muathe and Mwangi (2018); Mutuku, Muathe and James (2019). However, some banks which were put under statutory management between 2016 
- 2018 (Charterhouse Bank Itd. under statutory Management and Imperial Bank Itd. \& Case Bank) have not been salvaged to date. The situation therefore affects the entire economic standing of the country, suggesting that more research on the same are necessary, hence the current study.

Despite the noted wanting situation in the banking industry in Kenya the reviewed studies focused more on financial inclusion and e-commerce and ignored the regulatory framework as a measure of performance in banking (Musau, Muathe \& Mwangi, 2018; Mutuku, Muathe \& James,2019). However, it is established that regulatory tools enhance efficiency, improve quality and in the longrun boost quantity, hence improving performance (Roghanian, Rasli \& Gheysari, 2012; Abdrahamane, Xi, Alpha \& Kargbo, 2017; Yang, Gan \& Li, 2019). This study sought to examine effect of banks regulation on performance of commercial banks in Kenya. The study therefore, tested the following hypothesis:

H01: Regulatory framework has no significance effect on non-financial performance of commercial banks in Kenya.

H02: Regulatory framework has no significance effect on financial performance of commercial banks in Kenya.

\section{Methodology}

This study adopted two designs: a cross-sectional descriptive survey and explanatory research design. Accordingly, there was a multimethod which is used to strengthen a study's conclusions (Morse \& Niehaus, 2009). Multiple methods also allow researchers to use creativity in integrating qualitative and quantitative elements. This permit the researcher to collectively analyse qualitative and quantitative data, implement qualitative and quantitative components either concurrently or sequentially and framing the procedures within theoretical models (Wisdom, \& Creswell, 2013). Moreover, it provides a wider spectrum for more informed data interpretation (Johnson, Onwuegbuzie \& Turner, 2007). Consequently, cross-sectional descriptive survey was appropriate since it provided trends in commercial banks in Kenya and generated both qualitative and quantitative data through research questionnaires as suggested by (Koh \& Owen, 2000). On other hand explanatory research design identified the cause and effect, hence linking between the independent and dependent variables that pertained the research problem.

This study used 40 commercial banks in Kenya as target population, categorized as large, medium, and small size based on the market share. According to CBK (2018) commercial banks in operation on $31^{\text {st }}$ December, 2018 were 40 excluding those in statutory management. Hence the research carried out a survey on all of them. Further, a sample size of 181respondents obtained through proportional sampling technique was used and a ratio of 0.15 at 95 percent level of confidence was adapted from a Krejcie and Morgan's table for determining sample size (Krejcie \& Morgan, 1970). Additionally, the study used questionnaires to collect primary data and document review to obtain secondary data from annual publications from central bank in Kenya. Further, the study used two separate models for financial and non-financial measures to explain performance of commercial banks. The financial measures were Return on Equity (ROE), while non-financial measures were abbreviated as (NFP) which was an aggregated mean of the Likert scale constructs. The models indicated below were used.

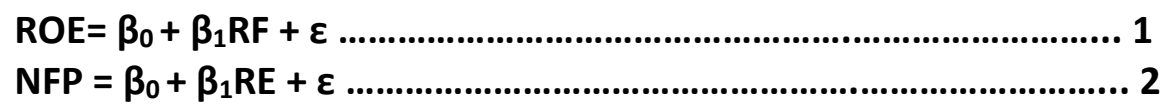


INTERNATIONAL JOURNAL OF ACADEMIC RESEARCH IN BUSINESS AND SOCIAL SCIENCES

Vol. 10, No. 10, 2020, E-ISSN: 2222-6990 @ 2020 HRMARS

Where: -

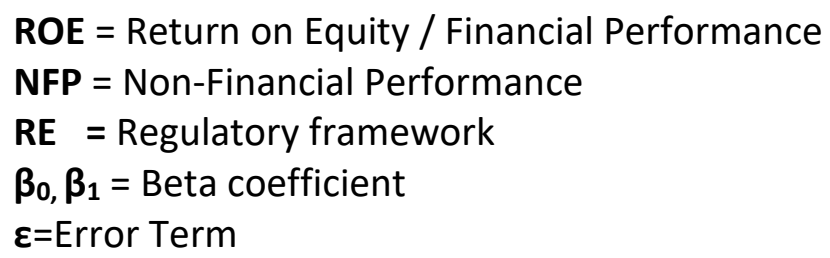

\section{Findings}

The presentation of the results includes the descriptive statistics, model summary and multiple regression analysis. Table1 presents the information on regulatory framework provided by respondents through a five-point Likert scale to measure the extent agreement with the suggested statements.

Table 1: Descriptive Statistics of Regulatory Framework

\begin{tabular}{lcc}
\hline Descriptions & \multicolumn{2}{c}{$\begin{array}{c}\text { Standard } \\
\text { Deviation }\end{array}$} \\
\hline $\begin{array}{l}\text { Protects bank from the losses. } \\
\text { Enables the banks to estimate the impact of the risk on the }\end{array}$ & 3.32 & 1.44 \\
capital employed. & 3.51 & 1.40 \\
Enhances financial standing & 3.53 & 1.45 \\
Ensures that the bank operations are manageable within acceptable & & \\
limits and are profitable. & 3.54 & 1.34 \\
Enables the management of working capital. & 3.56 & 1.08 \\
Provides security to the investors. & 3.57 & 1.41 \\
Helps banks to maintain market confidence. & 3.64 & 1.34 \\
Enables banks to deliver intra-bank daily liquidity information to & & \\
customers. & 4.04 & 0.81 \\
Enables banks to manage cash flows credit facilities. & 4.11 & 0.82 \\
Maintain adequate credit and enforces investment policies. & 4.09 & 1.17 \\
Improve asset value and gives alert against losses. & 4.11 & 0.97 \\
\hline Aggregate Mean Score and Standard Deviation & 3.73 & 1.21 \\
\hline
\end{tabular}

Table 1 indicate that, commercial banks in Kenya agreed to a moderate extent that regulatory framework protects banks from losses and that it enables the banks to estimate the impact of the risk on the capital employed. They also enhance financial standing, ensures that the bank operations are manageable within acceptable limits' and are profitable, enables the management of working capital, provides security to the investors and that it helps banks to maintain market confidence with mean scores of 3.32, 3.51, 3.53, 3.56, 3.57 and 3.64 respectively. Further, commercial banks agreed to a large extent that regulatory framework enables banks to deliver intra-bank daily liquidity information to customers, enables banks to manage cash flows credit facilities, maintain adequate credit and enforces investment policies, improve asset value and gives alert against losses with mean scores of 4.04, 4.11, 4.09 and 4.11 respectively. On average, the results indicate that banks agreed to a moderate extent that the regulatory framework enhanced performance with an aggregate mean score of 3.73 and standard deviation of 1.21 . 
INTERNATIONAL JOURNAL OF ACADEMIC RESEARCH IN BUSINESS AND SOCIAL SCIENCES Vol. 10, No. 10, 2020, E-ISSN: 2222-6990 @ 2020 HRMARS

In essence, regulatory framework was displayed as one that enhance a conducive banking environment to customers and the industry as a whole. In this case therefore banks benefit from high efficiency, effectiveness and productivity, while the customers benefit from better services and security of their savings.

To establish the effect of regulatory framework on performance of Commercial banks in Kenya, two regression models, for NFP and ROE were established as shown:

$\mathrm{ROE}=\beta_{0}+\beta_{1} \mathrm{RF}+\varepsilon$

$N F P=\beta_{0}+\beta_{1} R E+\varepsilon$

The model summary that reveals the coefficients of determination is presented in Table 2 .

Table 2: Model Summary of Financial measurers

\begin{tabular}{lrrrrr}
\hline Model & R & R Square & \multicolumn{1}{c}{$\begin{array}{c}\text { Adjusted R } \\
\text { Square }\end{array}$} & $\begin{array}{c}\text { Std. Error of } \\
\text { the Estimate }\end{array}$ & \multicolumn{2}{l}{ Sig. F Change } \\
\hline ROE & $.229^{\mathrm{a}}$ & .053 & .046 & 22.43676 & 0.006 \\
NFP & $.711^{\mathrm{a}}$ & .506 & .502 & .70560003 & 0.000 \\
\hline
\end{tabular}

The results in table 2 show an adjusted R-square value of 0.046 for the regression model ROE financial performance with regulatory framework. The model shows an overestimation, it indicates that $4.6 \%$ of variation in ROE of the commercial banks in Kenya can be explained by regulatory framework. Scholars not that studies that attempts to predict human behaviour tend to have R-squared values less than $50 \%$ due to variation on individual conduct (Hamilton, Ghert \& Simpson, 2015). In this case regulatory framework in banking can possibly alter the behaviour of management and employees generally, changing business activities and finally affect performance (Jones, 2013). The study shows a small adjusted $\mathrm{R}^{2}$, however this does not guarantee that there was a weak relationship, given that the statistics are largely influenced by variation due the restriction on regulatory framework. The study clearly demonstrates that legal restrictions and too much control imposed the on commercial banks reduces banks' return on equity (ROE). These findings are also supported by other studies by Shen \& Chang (2006), Jones (2013) and Hamilton et al. (2015).

The results also showed an adjusted R-square value of 0.502 for the regression model linking NFP with regulatory framework. The results indicate that there was no overestimation of the model as well. This implies that up to $50.2 \%$ of variation in NFP of the commercial banks in Kenya can be explained by the regulatory framework. These findings are consistent with that of a study by Elnihewi, Fadzil, and Mohamed, (2014). The study found there was no great impact on relationship between normative pressures and firm performance through non-financial performance measures. 
INTERNATIONAL JOURNAL OF ACADEMIC RESEARCH IN BUSINESS AND SOCIAL SCIENCES Vol. 10, No. 10, 2020, E-ISSN: 2222-6990 @ 2020 HRMARS

Table 3: ANOVA

\begin{tabular}{llrrrrr}
\hline Model & Sum of Squares & df & $\begin{array}{l}\text { Mean } \\
\text { Square }\end{array}$ & F & Sig. \\
\hline \multirow{2}{*}{ ROE } & Regression & 3857.013 & 1 & 3857.013 & 7.662 &.$^{006^{\mathrm{b}}}$ \\
& Residual & 69470.330 & 138 & 503.408 & & \\
& Total & $\mathbf{7 3 3 2 7 . 3 4 2}$ & $\mathbf{1 3 9}$ & & & \\
& Regression & 70.294 & 1 & 70.294 & 141.189 & $.000^{\mathrm{b}}$ \\
NFP & Residual & 68.706 & 138 & .498 & & \\
& Total & $\mathbf{1 3 9 . 0 0 0}$ & $\mathbf{1 3 9}$ & & & \\
\hline \multicolumn{2}{l}{ Predictors: (Constant), Regulatory framework } \\
\hline
\end{tabular}

The results in Table 3 on the analysis of variance indicate that for the regression model linking ROE with regulatory framework, the $F$ statistic value of 7.662 was significant at $5 \%$ level of significance (Sig $=0.006)$. These findings imply that the model linking financial performance with regulatory framework, is that regulatory framework has a contribution to changes in financial performance of commercial banks in Kenya. It was also established in table 3, for the regression model linking nonfinancial performance with regulatory framework, the F statistic value of 141.189 was also significant at $5 \%$ level of significance (Sig $=0.000$ ). The findings for model coefficients are presented in table 4 .

Table 4: Regression Model Coefficients

\begin{tabular}{|c|c|c|c|c|c|c|}
\hline \multirow[t]{2}{*}{ Model } & & \multicolumn{2}{|c|}{$\begin{array}{l}\text { Unstandardized } \\
\text { Coefficients }\end{array}$} & \multirow{2}{*}{$\begin{array}{r}\text { Standardized } \\
\text { Coefficients } \\
\text { Beta }\end{array}$} & \multirow[t]{2}{*}{$t$} & \multirow[t]{2}{*}{ Sig. } \\
\hline & & B & Std. Error & & & \\
\hline \multirow{2}{*}{ NFP } & (Constant) & 3.787 & 1.896 & & 1.997 & .048 \\
\hline & & 5.268 & 1.903 & .229 & 2.768 & .006 \\
\hline \multirow{2}{*}{ ROE } & (Constant) & $\begin{array}{r}9.322 \mathrm{E}- \\
017\end{array}$ & .060 & & .000 & 1.000 \\
\hline & $\begin{array}{l}\text { Regulatory } \\
\text { framework }\end{array}$ & .711 & .060 & .711 & 11.882 & .000 \\
\hline
\end{tabular}

Finding in table 4 implies that the model linking financial performance with regulatory framework was reasonably and fit. In this study the model identified the impact of regulatory framework on ROE and non-financial measures of commercial banks in Kennya. This model put more emphasis on need to be cautious when imposing legal restrictions in business. The model clearly indicates that regulations of commercial banks in Kenya provide positive results but not highly significant. These results were also established in a study carried out by Were and Wambua, (2014). However, a high ROE indicates that a company is using contributions of the investors in an efficient manner, hence encouraging them invest more. Moreover, the ratio (ROE) is an important measurer for a company's earnings performance hence an indication on how effective they can utilize the investor's capital.

This argument is also supported by a study by Kijewska, (2016). In addition, the results on nonfinancial measurers indicated, the implementation of the same assist the organisations with ideas specifically on customers' needs. Further non-financial measurers link the company with its strategy such as sales and delivery strategies. Other strategies include the brand awareness and 
INTERNATIONAL JOURNAL OF ACADEMIC RESEARCH IN BUSINESS AND SOCIAL SCIENCES Vol. 10, No. 10, 2020, E-ISSN: 2222-6990 @ 2020 HRMARS

empowerment, training and development of the employees to equip them with better skills and enhance their capabilities. Non-financial measures were therefore displayed as valuable intangible assets for the commercial banks, which in the long run benefit the banks with tangible assets such as financial revenue. Further, this study presents non-financial measures as indicators, which give full picture on why a particular service is not up to standard, example is case of drop of sales, the organisation may find ways of improving on innovation.

\section{Conclusion and Policy Recommendation Conclusion}

This study sought to examine the effect of regulatory framework on the performance of commercial banks in Kenya. The specific objective was to determine the effect regulatory framework on the context of commercial banks in Kenya. Findings indicate therefore, regulatory framework has a statistically significance on the performance of commercial banks in Kenya, though not to a higher extent. Moreover, both financial and non-financial measures of performance are relevant in the banking sector and growth of Kenyan economy. The study further established that incautious restrictions, or restrictions based on self-interests by the government or their agents can disadvantage the banking business. On other hand, prudential restrictions directed toward promoting economic growth, will expand the market hence sustaining the country's economy.

\section{Policy Implications}

Based on the study findings, a set of policy options are recommended for improving performance of commercial banks in Kenya. The study established that regulatory framework fairly improves performance of commercial banks in Kenya. Further, the literature revealed that CBK has in place prudential guidelines for banks development, which could be termed as sufficient for banking stability. Nevertheless, the CBK need to adopt diversity-enhancing policies, which may be temporary, to be adopted only after diversity-reducing policies are done away with. The diversity-enhancing policies must support the strong, diverse, safe and ethical business models. Moreover, the regulators must be accountable on the legal restriction imposed on the commercial banks, implying that they should not enforce restrictions on the expense of adversely affecting the investors' motivation to invest.

\section{Limitation and Future Research}

This study sought to investigate the effect of regulatory framework in the context of commercial banks in Kenya. The researcher administered both open and closed ended questionnaires, and an online document review, which provided independent responses and specific data for Kenya commercial banks' ROE for years; 2016, 2017 and 2018, which were regarded as accurate to the expectation of the researcher. Moreover, the researcher conducted a cross-sectional data collection procedure, which was important for current required data. Regulatory framework was defined as legal infrastructure for regulating, licensing process, liquidity management, capital adequacy and credit growth in commercial banks to ensure bank sustainability and investors' protection. The nonfinancial performance measures such as customer satisfaction learning and growth and Internal processes were also investigated. Other studies can be carried out and use other regulatory parameters to examine the performance of commercial banks in Kenya. 
INTERNATIONAL JOURNAL OF ACADEMIC RESEARCH IN BUSINESS AND SOCIAL SCIENCES

Vol. 10, No. 10, 2020, E-ISSN: 2222-6990 @ 2020 HRMARS

\section{References}

Abdrahamane, K., Xi, L., Alpha, B. B., \& Kargbo, M. (2017). An Empirical Study on Government Regulation, Bank Risk and Bank Performance: Case of Mali. Journal of Management, 5(1), 1-8.

Allen, F., Otchere, I., \& Senbet, L. W. (2011). African financial systems: A review. Review of Development Finance, 1(2), 79-113.

Alshatti, A. S. (2015). The effect of the liquidity management on profitability in the Jordanian commercial banks. International Journal of Business and Management, 10(1), 62.

Bandeira-de-Mello, R., Marcon, R., \& Alberton, A. (2011). Performance effects of stakeholder interaction in emerging economies: evidence from Brazil. BAR-Brazilian Administration Review, 8(3), 329-350.

Barth, J., Caprio, G., \& Levine, R. (2001). Bank regulation and supervision: What Works and what doesn't. World Bank, mimeo.

Boussanni, A., Desrochers, J., \& Préfontaine, J. (2008). Liquidity risk financial disclosure: the case of large European financial groups. International Business \& Economics Research Journal (IBER), 7(7).

Buch, C. (2018). Structural changes in banking after the crisis, CGFS Papers No 60

Chakrabarty, K. C. (2013). Regulation for Financial Consumer Protection: Present Status and Future Directions. In Opening Remarks at Conference of Principal Code Compliance Innovations in India: From Agent Banking to Universal Identification (Vol. 87).

CKB. (2009). A Meeting of The Actuarial Society of Kenya

CBK Newsletter Issue 1/March2013

Collins, C. J. (2020). Expanding the resource-based view model of strategic human resource management. The International Journal of Human Resource Management, 1-28.

Djalilov, K., \& Piesse, J. (2019). Bank regulation and efficiency: Evidence from transition countries. International Review of Economics \& Finance, 64, 308-322.

Elnihewi, I., Fadzil, F. H., \& Mohamed, R. (2014). The effect of institutional factors on the organizational performance through performance measures of commercial banks in Libya. Procedia-Social and Behavioral Sciences, 164, 635-640.

Graybeal, P., Franklin, M., \& Cooper, D. (2018). Distinguish between Financial and Managerial Accounting. Principles of Accounting, Volume 2: Managerial Accounting.

Griffith-Jones, S. (2016). Achieving financial stability and growth in Africa. In Financial Liberalisation (pp. 133-175). Palgrave Macmillan, Cham.

Ghebregiorgis, F., \& Atewebrhan, A. (2016). Measurement of bank profitability, risk and efficiency: The case of the Commercial Bank of Eritrea and Housing and Commerce Bank of Eritrea. African Journal of Business Management, 10(22), 554-562.

Gu, J., Chua, P. F., \& Trebs, L. (2020). The Future of International Development Cooperation: Case Studies of Sri Lanka and Kenya.

Halcomb, E. J. (2019). Mixed methods research: The issues beyond combining methods.

Hamilton, D. F., Ghert, M., \& Simpson, A. H. R. W. (2015). Interpreting regression models in clinical outcome studies.

Heimler, A. (2006). Competition Policy, Antitrust enforcement and banking: some recent developments. Italian Competition Authority, Roma, Italy. 
INTERNATIONAL JOURNAL OF ACADEMIC RESEARCH IN BUSINESS AND SOCIAL SCIENCES Vol. 10, No. 10, 2020, E-ISSN: 2222-6990 @ 2020 HRMARS

Henry, E., Robinson, T. R., \& van Greuning, J. H. (2012). Financial analysis techniques. Financial reporting \& analysis, 327-385.

Iqbal, B. A., \& Sami, S. (2017). Role of banks in financial inclusion in India. Contaduría y administracion, 62(2), 644-656.

Jones, K. K. (2013). The impact of legislation on the organization: Evaluating the impact of corporate governance regulation on the internal audit function.

Johnson, T., Gunatilake, H. M., Niimi, Y., Khan, M. E., Jiang, Y., Hasan, R., ... \& Huang, B. (2009). Financial sector development, economic growth, and poverty reduction: A literature review. Asian Development Bank Economics Working Paper Series, (173).

Kamau, A., \& Were, M. (2013). What drives banking sector performance in Kenya. Global Business and Economics Research Journal, 2(4), 45-59.

Kamande, E. G. (2017). The effect of bank specific factors on financial performance of commercial banks in Kenya (Doctoral dissertation).

Kenya. (2007), Kenya Vision 2030: The Popular Version, Nairobi. www.vision2030.go.ke

Kijewska, A. (2016). Determinants of the return on equity ratio (ROE) on the example of companies from metallurgy and mining sector in Poland. Metalurgija, 55(2), 285-288.

Kim, M., Song, J., \& Triche, J. (2015). Toward an integrated framework for innovation in service: A resource-based view and dynamic capabilities approach. Information Systems Frontiers, 17(3), 533-546

Kraaijenbrink, J., Spender, J.-C., \& Groen, A. J. (2010). The resource-based view: a review and assessment of its critiques. Journal of Management, 36(1), 349-372.

Kor, Y. Y., \& Mahoney, J. T. (2004). Edith Penrose's (1959) contributions to the resource-based view of strategic management. Journal of management studies, 41(1), 183-191.

Kor, Y. Y., Mahoney, J. T., Siemsen, E., \& Tan, D. (2016). Penrose's The Theory of the Growth of the Firm: An exemplar of engaged scholarship. Production and Operations Management, 25(10), 1727-1744.

Levine, R., \& Barth, J. (2001). Bank regulation and supervision

Liang, H. Y., \& Reichert, A. (2006). The relationship between economic growth and banking sector development. Banks \& bank systems, (1, № 2), 19-35.

Organisation for Economic Co-operation and Development. (2014). The Governance of Regulators. OECD Publishing.

Li, T. (2007). Banking Regulation around the World: Patterns, Determinants, and Impact. Journal of Emerging Market Finance, 6(1), 61-122.

Hajer, C., \& Anis, J. (2018). Analysis of the impact of governance on bank performance: case of commercial Tunisian banks. Journal of the Knowledge Economy, 9(3), 871-895.

Harrison, J. S., Bosse, D., \& Phillips, R. A. (2007). Stakeholder Theory and Competitive Advantage. In Academy of Management proceedings (Vol. 2007, No. 1, pp. 1-6). Briarcliff Manor, NY 10510: Academy of Management.

Hodge, G. (2007). Regulatory frameworks for urban services. Background Discussion Paper, OECD. http://www. OECD. org/gov/regulatory-policy/39218313.

Mario, M. (2012)., Stakeholder Theory(ies): Ethical Ideas and Managerial Action, Vol. 109, No. 1, pp. 67-82.

Mahoney, J. T., \& Pandian, J. R. (1992). The resource-based view within the conversation of strategic management. Strategic management journal, 13(5), 363-380. 
INTERNATIONAL JOURNAL OF ACADEMIC RESEARCH IN BUSINESS AND SOCIAL SCIENCES Vol. 10, No. 10, 2020, E-ISSN: 2222-6990 @ 2020 HRMARS

Manzaneque-Lizano, M., Alfaro-Cortés, E., \& Priego de la Cruz, A. M. (2019). Stakeholders and Long-Term Sustainability of SMEs. Who Really Matters in Crisis Contexts, and When. Sustainability, 11(23), 6551.

Malyshev, N. (2008). The evolution of regulatory policy in OECD countries. Organisation for Economic Co-Operation and Development, 1-30.

Medeiros, S. A. D., Christino, J. M. M., Goncalves, C. A., \& Goncalves, M. A. (2020). Relationships among dynamic capabilities dimensions in building competitive advantage: a conceptual model. Gestão \& Producão, 27(1).

M'Amanja, D. A. (2015). Financial inclusion, regulation and stability: Kenyan experience and perspective. In A paper presented at the UNCTAD's Multi-Year Expert Meeting on Trade, Services and Development held in Geneva, Switzerland.

Mwega, F. M. (2016). Financial regulation in Kenya: Balancing inclusive growth with financial stability. In Achieving Financial Stability and Growth in Africa (pp. 99-122). Routledge.

Ping, H. W. (2014). Banking Regulation in China: The Role of Public and Private Sectors. Palgrave Macmillan.

Qaqaya, H. (2008). The effects of anti-competitive business practices on developing countries and their development prospects.

Ramírez-Corcoles, Y., \& Manzaneque-Lizano, M. (2015). The relevance of intellectual capital disclosure: empirical evidence from Spanish universities. Knowledge Management Research \& Practice, 13(1), 31-44.

Roghanian, P., Rasli, A., \& Gheysari, H. (2012). Productivity through effectiveness and efficiency in the banking industry. Procedia-Social and Behavioral Sciences, 40, 550-556.

Roussakis, E. N. (1997). Global banking: origins and evolution. Revista de Administracão de Empresas, 37(4), 45-53.

Shen, C. H., \& Chang, Y. H. (2006). Do regulations affect banking performance? Government governance may matter. Contemporary Economic Policy, 24(1), 92-105

Soimakallio, S., \& Saikku, L. (2012). CO2 emissions attributed to annual average electricity consumption in OECD (the Organisation for Economic Co-operation and Development) countries. Energy, 38(1), 13-20.

Were, M., \& Wambua, J. (2014). What factors drive interest rate spread of commercial banks? Empirical evidence from Kenya. Review of development Finance, 4(2), 73-82.

Wisdom, J., \& Creswell, J. W. (2013). Mixed methods: integrating quantitative and qualitative data collection and analysis while studying patient-centered medical home models. Rockville: Agency for Healthcare Research and Quality.

Wojcik, P. (2015). Exploring links between dynamic capabilities perspective and resource-based view: A literature overview. International Journal of Management and Economics, 45(1), 83-107.

Yang, Z., Gan, C., \& Li, Z. (2019). Role of bank regulation on bank performance: Evidence from Asia-Pacific commercial banks. Journal of Risk and Financial Management, 12(3), 131. 